2015

\title{
The A. C. Gibson Site (41WD1), a Middle Caddo Period Component on the Sabine River in Wood County, Texas
}

Timothy K. Perttula

Heritage Research Center, Stephen F. Austin State University

Follow this and additional works at: https://scholarworks.sfasu.edu/ita

Part of the American Material Culture Commons, Archaeological Anthropology Commons, Environmental Studies Commons, Other American Studies Commons, Other Arts and Humanities Commons, Other History of Art, Architecture, and Archaeology Commons, and the United States History Commons

Tell us how this article helped you.

This Article is brought to you for free and open access by the Center for Regional Heritage Research at SFA ScholarWorks. It has been accepted for inclusion in Index of Texas Archaeology: Open Access Gray Literature from the Lone Star State by an authorized editor of SFA ScholarWorks. For more information, please contact cdsscholarworks@sfasu.edu. 
The A. C. Gibson Site (41WD1), a Middle Caddo Period Component on the Sabine River in Wood County, Texas

\section{Creative Commons License}

\section{(c) (1) \&}

This work is licensed under a Creative Commons Attribution-NonCommercial 4.0 International License 


\title{
The A. C. Gibson Site (41WD1), a Middle Caddo Period Component on the Sabine River in Wood County, Texas
}

\author{
Timothy K. Perttula
}

\section{INTRODUCTION}

The A. C. Gibson site (41WD1) is an ancestral Caddo site of probable Middle Caddo period (ca. A.D. 1200-1400) age in the Sabine River basin in the Post Oak Savannah of East Texas (Figure 1). The site is on a natural alluvial knoll in the floodplain of the Sabine River and Cottonwood Creek, just north of Cedar Lake, an old channel of the river. The site has been known since the early 1930s by collectors and site looters, early University of Texas (UT) archeologists, and then by later archaeologists from UT and Southern Methodist University, but it has heretofore not been scrutinized by Caddo archaeologists to any serious degree.

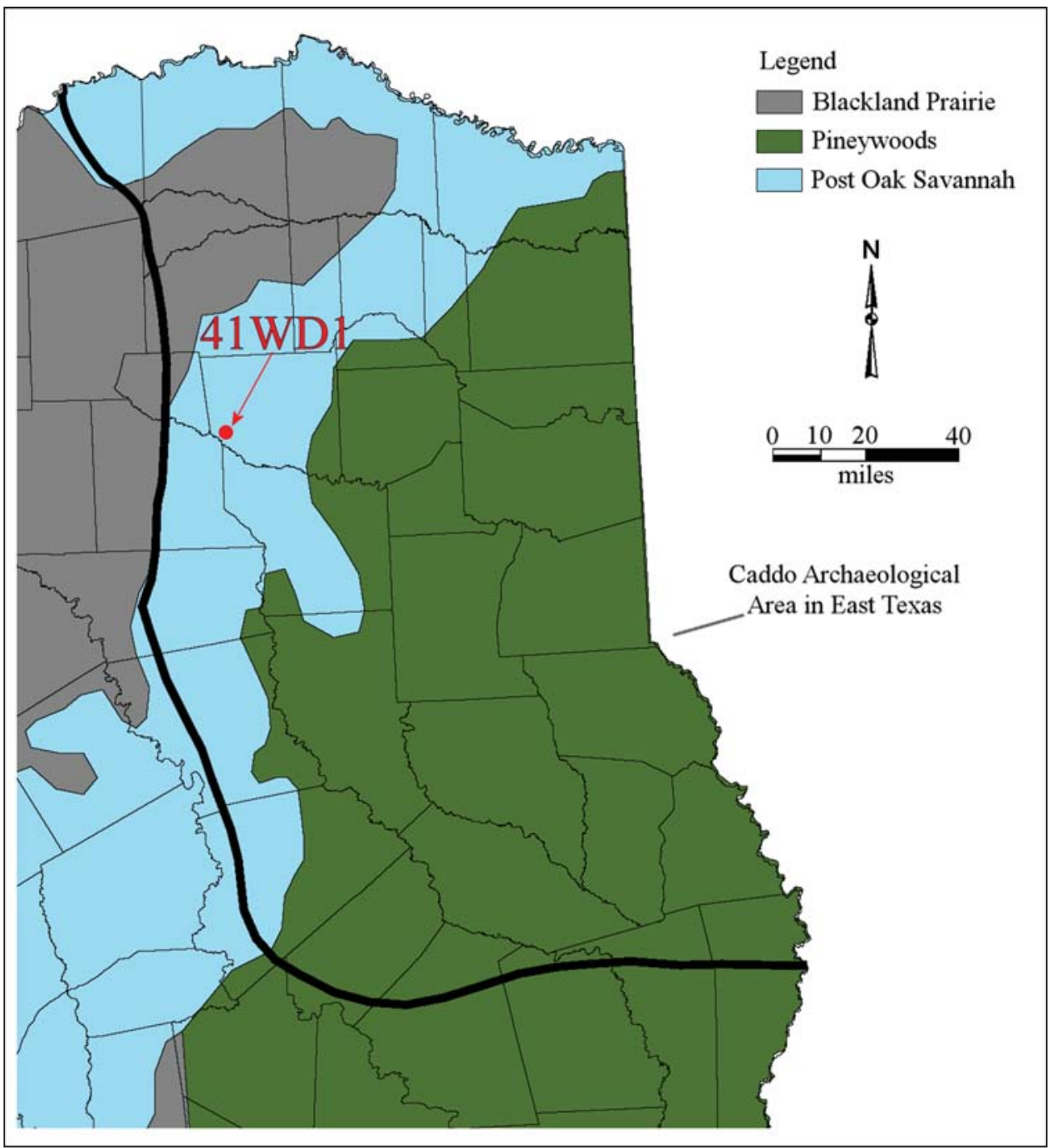

Figure 1. The location of the A.C. Gibson site in East Texas. 


\section{SITE SETTING AND INVESTIGATIONS}

UT archaeologists, led by A. T. Jackson, excavated the A. C. Gibson site in July 1934. The site was known to contain midden deposits with concentrations of mussel shell as well as ancestral Caddo burials. In 1932, the midden had been looted by unknown individuals, and they had encountered in one part of the midden a thick concentration of mussel shells. Underneath the area of mussel shells was a burial with two ceramic vessels as funerary offerings; the kinds of vessels or whether they were decorated was not ascertained by UT archaeologists.

In the 1934 UT investigations, two burials were encountered and excavated in the midden. The first, Burial S-1, was encountered at a depth of ca. $38 \mathrm{~cm}$ bs. It was a flexed child burial; found with the child were two mussel shell valves and an expanding stem dart point. Based on the recovery of both Late Archaic and Woodland period dart points in the midden excavations (see below), it is possible that this flexed burial is associated with the pre-A.D. 800 occupation of the A. C. Gibson site. Another possibility is that the mussel shell and the dart points were simply incidental midden inclusions that ended up in the burial pit and were not actually associated funerary offerings with the child. However, a Woodland period flexed burial was excavated in Midden A at the Osborn site (41WD73) on Lake Fork Creek (Bruseth and Perttula 1981:36 and Figure 3-35); this burial had no funerary offerings.

The second burial excavated by UT archaeologists at the A. C. Gibson site, Burial S-2, was found at a depth of ca. $59 \mathrm{~cm}$ bs in the midden. The burial had two adults placed in an extended supine position in a burial pit; one adult was oriented with their head at the eastern side of the grave, facing west, while the second individual had their head at the western side of the grave and thus facing east. Placed in the grave with these two individuals were two ceramic vessels and a plain elbow pipe (see below). One of the vessels was a red-slipped jar (Sanders Plain) while the other was a plain bowl with a scalloped lip and appliqued rim nodes. Based on the funerary offerings in Burial S-2, the burial was interred during some part of the Middle Caddo period; the midden itself is probably mainly a Middle Caddo period accumulation, as suggested by the decorative styles on the utility and fine ware sherds in the recovered artifact assemblage (see below).

Malone (1972) next visited the site in 1971 prior to the planned construction of Lake Mineola on the Sabine River. He noted that the site was located on a knoll in the floodplain of the Sabine River. In 1976, archaeologists from Southern Methodist University visited the site. They noted the midden deposits there, and commented that the site was known to have been looted and collected previously. To my knowledge, no professional archaeologist has visited or done any investigations at the A. C. Gibson site since 1976.

\section{ARTIFACT ASSEMBLAGE}

The artifact assemblage collected by UT archaeologists in 1934 from the A. C. Gibson site at the Texas Archeological Research Laboratory at The University of Texas at Austin includes several chipped stone tools, a possible sandstone gorget fragment, 584 plain and decorated ceramic sherds, an elbow pipe, and two pipe sherds from either a long-stemmed Red River style pipe or an L-shaped elbow pipe. The recovered artifacts are from Late Archaic (ca. 5000-2500 years B.P.), Woodland (ca. 2500-1150 years B.P.), and Middle Caddo period (ca. A.D. 1200-1400) occupations of the site.

\section{Chipped Stone Tools}

There are several chipped stone tools from the 1934 UT excavations in the A. C. Gibson midden. They include two biface preforms of local quartzite and brown chert, a quartzite dart point tip, and a resharpened Late Archaic Morrill dart point (see Turner et al. 2011:139) made from local quartzite; it has small barbs 
and a resharpened blade. There are also three Woodland period Gary dart points, probably var. Camden (see Schambach 1982), all made from local quartzite. Stem widths on these dart points range from 10.5-15.9 mm.

\section{Possible Sandstone Gorget Fragment}

The possible sandstone gorget fragment from the site is a thin $(5.4 \mathrm{~mm})$, flat, and polished piece of quartzitic sandstone (Figure 2); the broken area may have had drilled holes for suspension of the possible gorget. The fragment is $55.0 \mathrm{~mm}$ in length and $54.5 \mathrm{~mm}$ in width.

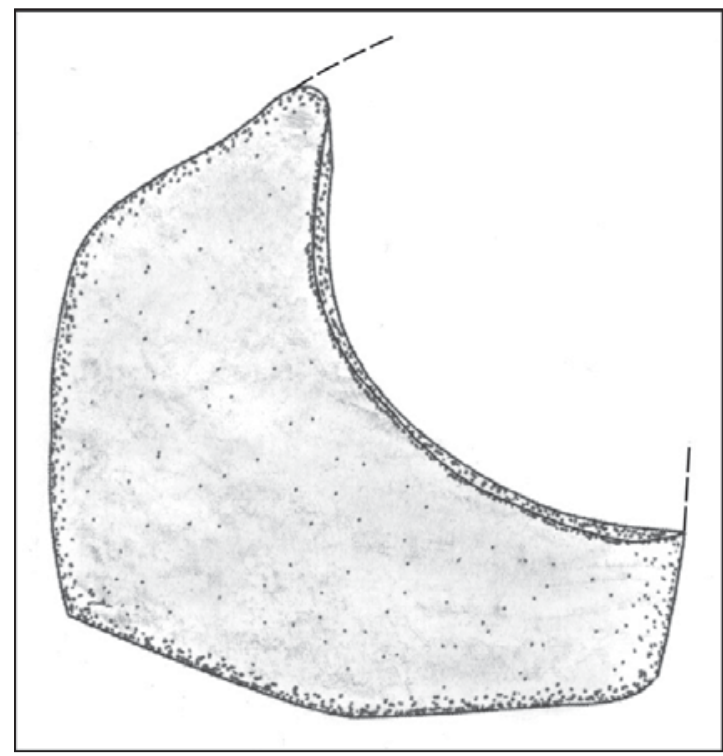

Figure 2. Possible sandstone gorget fragment from the A. C. Gibson site.

\section{Ceramic Sherds}

The Caddo ceramic assemblage from the A. C. Gibson site includes 584 sherds from plain ware, utility ware, and fine ware vessels. As with most upper Sabine River basin Caddo ceramic assemblages (Perttula 2015:Table 1), the vessels were tempered almost exclusively with grog or crushed sherds (96.9 percent). Only 3.1 percent of the sherds are from bone-tempered vessels (Table 1), and most of these sherds are from plain wares.

Table 1. Use of temper in ceramic sherds from different wares in the A. C. Gibson site assemblage.

\begin{tabular}{lccccccr}
\hline & \multicolumn{7}{c}{ Temper } \\
Ware & rim & $\begin{array}{l}\text { Grog } \\
\text { body }\end{array}$ & base & rim & $\begin{array}{l}\text { Bone } \\
\text { body }\end{array}$ & base & N \\
\hline Plain & 13 & 427 & 24 & - & 14 & 2 & 480 \\
Utility & 21 & 50 & - & - & - & - & 71 \\
Fine & 5 & 24 & 1 & 1 & 2 & - & 33 \\
\hline Totals & 39 & 501 & 25 & 1 & 16 & 2 & 584 \\
\hline
\end{tabular}


There are 40 rim sherds in the assemblage. The majority of the rim sherds are from utility ware jars ( 53 percent), but 32.5 percent are from plain wares, indicating that plain ware vessels were common overall in the assemblage. Only 15.0 percent of the rim sherds are from fine ware vessels (see Table 1).

Decorated sherds comprise 17.8 percent of the ceramic assemblage. The plain to decorated sherd ratio of the assemblage is a high 4.61 (see Table 1). Sherds from utility ware vessels (i.e., sherds with wet paste decorations) account for about 68 percent of the decorated sherds and more than 77 percent of the decorated rim sherds in the assemblage.

The utility wares from the A. C. Gibson site are predominantly from vessels with incised decorative elements (Table 2). Sherds with incised decorative elements comprise 63 percent of the utility ware sherds, and 76 percent of the rim sherds from utility ware vessels. Other relatively common utility wares in the ceramic assemblage are from vessels with punctated (15 percent), brushed ( 8 percent), and appliqued ( 7 percent) vessels (Table 2).

Table 2. Decorative elements in sherds from utility ware vessels from the A.C. Gibson site.

\begin{tabular}{lllll}
\hline & \multicolumn{3}{c}{ Grog } & Bone \\
Decorative method & rim & body & rim & body \\
\hline
\end{tabular}

\section{Appliqued}

appliqued fillet, straight

appliqued lugs, vertical

appliqued node

-
1
-

\section{Appliqued-Punctated}

appliqued node and tool punctated rows

\section{Brushed}

parallel brushed marks

$\begin{array}{lll}- & - & 1 \\ - & - & 2 \\ - & - & 2\end{array}$

\section{Incised}

cross-hatched lines

diagonal lines, L-R

diagonal lines, $\mathrm{R}-\mathrm{L}$

diagonal lines, closely-spaced sets,

$\mathrm{R}-\mathrm{L}$

diagonal opposed lines

diagonal opposed and parallel lines

horizontal lines

horizontal and diagonal opposed lines

parallel lines

straight line

vertical or near vertical lines

2
-
6
1
4
-
-
-
-

\section{Incised-Punctated}

incised triangle element above row of tool punctations at rim-body juncture 
Table 2. Decorative elements in sherds from utility ware vessels from the A.C. Gibson site, cont.

\begin{tabular}{|c|c|c|c|c|c|}
\hline \multirow[b]{2}{*}{ Decorative method } & \multicolumn{2}{|c|}{ Grog } & \multicolumn{2}{|c|}{ Bone } & \multirow[b]{2}{*}{$\mathrm{N}$} \\
\hline & rim & body & rim & body & \\
\hline Lip Notched & 1 & - & - & - & 1 \\
\hline \multicolumn{6}{|l|}{ Pinched } \\
\hline parallel pinched ridges & - & 1 & - & - & 1 \\
\hline \multicolumn{6}{|l|}{ Punctated } \\
\hline circular punctated row & - & 1 & - & - & 1 \\
\hline fingernail punctated rows & - & 4 & - & - & 4 \\
\hline tool punctated rows & - & 3 & - & - & 3 \\
\hline tool punctated row at lip & 1 & - & - & - & 1 \\
\hline tool punctated row on ext. folded lip & 1 & - & - & - & 1 \\
\hline tool punctated row below lip & 1 & - & - & - & 1 \\
\hline Totals & 21 & 50 & - & - & 71 \\
\hline
\end{tabular}

L-R, left (incised line begins at top of rim) to right (incised line ends to the right at bottom of rim); R-L, right (incised line begins at the top of rim) to left (incised line ends to the left at bottom of rim)

The appliqued rim and body sherds are from jars with fillets that ran down the body of jars, dividing the vessel bodies into undecorated panels, or have appliqued nodes and vertical appliqued lugs on the rim (see Table 2); these latter sherds may be from Monkstown Fingernail Impressed vessels (see Suhm and Jelks 1962:109). One appliqued-punctated body sherd (Figure 3a) may also be from a Monkstown Fingernail Impressed jar that has an appliqued node amidst rows of punctations.

The occurrence of a few brushed sherds ( 8.5 percent of the utility ware sherds and 5.8 percent of all the decorated sherds) in the A. C. Gibson site decorated sherd assemblage is notable because sherds from brushed utility ware vessels, particularly jars, are a distinctive characteristic of both Middle, Late, and Historic Caddo sites in much of East Texas. Furthermore, the rarity of brushed vessel sherds suggests that the A. C. Gibson site was occupied during some part of the Middle Caddo period. In the East Texas Caddo ceramic sherd database, only a few ca. A.D. 1200-1430 sites have assemblages with high proportions of brushed sherds; these occur in the mid-Sabine and Big Cypress Creek drainage basins (Perttula 2015:Table 1 and Figure 5). Late Caddo sites in many parts of East Texas, including parts of the upper Sabine River basin, on the other hand, tend to have considerable amounts of brushed sherds in ceramic assemblages.

Incised rim and body sherds are primarily from Canton Incised jars. They have cross-hatched (see Figure 3b), diagonal opposed (see Figure 3c, e-f), diagonal (see Figure 3d), vertical, and sets of diagonal and diagonal opposed (see Figure 3g) incised lines (see Suhm and Jelks 1962:23 and Plate 12). One horizontal incised body sherd (see Table 2) may be from a Davis Incised or East Incised bowl.

There is only one lower rim-body sherd in the assemblage from an incised-punctated vessel (see Table 2), probably a grog-tempered Canton Incised jar. This sherd has a row of tool punctations at the rim-body juncture, and the rim itself has sets of diagonal opposed lines that would have formed incised triangles around the vessel rim. 


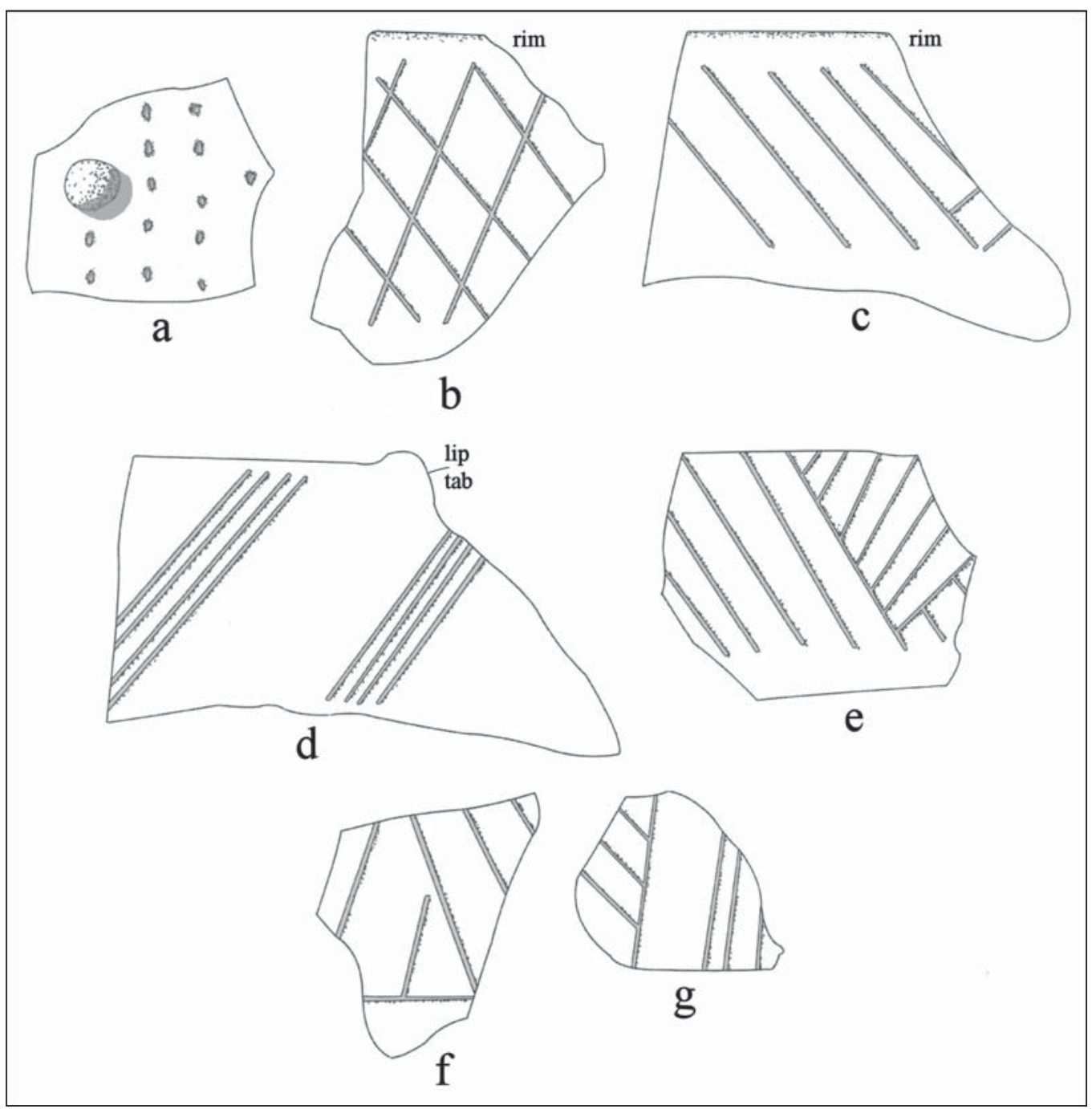

Figure 3. Decorative elements on utility ware rim and body sherds from the A. C. Gibson site:, a, appliqued-punctated; b-g, incised rim or body sherds.

The A. C. Gibson utility wares include one lip notched rim (see Table 2). The notching of the lips of vessels at the sole rim decoration is an apparently distinctive decorative method in a number of different ca. A.D. 900-1400 Caddo communities primarily in the upper Red and upper and middle Sabine River basins (Perttula 2015:Figure 9).

There is one body sherd with parallel pinched ridges as the decorative element in the utility wares at the A. C. Gibson site. This is from a Monkstown Fingernail Impressed jar, as they will have "pinches placed in rows" (Suhm and Jelks 1962:109) on the rim and/or body of vessels.

There are sherds with circular, fingernail, and tool punctated decorative elements in the A. C. Gibson ceramic assemblage (see Table 2). These may be primarily from undefined varieties of Monkstown Fingernail Impressed that have rows of punctations. One bowl rim sherd has a row of tool punctates at the vessel lip and another rim sherd has a row of tool punctations on the edge of its exterior folded lip.

The fine ware sherds from the A. C. Gibson site include sherds from either engraved or red-slipped vessels; red-slipped sherds comprise 55 percent of the fine ware sherds in the assemblage (Table 3). Three of the engraved sherds (20 percent) are from carinated bowls with interior and exterior red-slipped surfaces. 
Table 3. Decorative elements in sherds from fine ware vessels from the A.C. Gibson site.

\begin{tabular}{|c|c|c|c|c|c|}
\hline \multirow[b]{2}{*}{ Decorative method } & \multicolumn{2}{|c|}{ Grog } & \multicolumn{2}{|c|}{ Bone } & \multirow[b]{2}{*}{$\mathrm{N}$} \\
\hline & rim & body & rim & body & \\
\hline \multicolumn{6}{|l|}{ Engraved } \\
\hline cross-hatched lines & 1 & - & - & - & 1 \\
\hline sets of cross-hatched lines & - & 1 & - & - & 1 \\
\hline curvilinear lines & - & 2 & - & - & 2 \\
\hline $\begin{array}{l}\text { curvilinear lines, sets, and vertical and } \\
\text { diagonal lines }\end{array}$ & - & 1 & - & - & 1 \\
\hline diagonal lines, L-R & - & $1^{*}$ & - & - & 1 \\
\hline diagonal lines, $\mathrm{R}-\mathrm{L}$ & - & $1^{*}$ & - & - & 1 \\
\hline diagonal opposed lines & - & - & 1 & - & 1 \\
\hline horizontal lines & 2 & - & - & - & 2 \\
\hline horizontal and diagonal opposed lines & - & 2 & - & - & 2 \\
\hline parallel lines & - & 1 & - & - & 1 \\
\hline $\begin{array}{l}\text { parallel lines and excised pendant } \\
\text { triangles }\end{array}$ & - & $1^{*}$ & - & - & 1 \\
\hline straight line & - & - & - & 1 & 1 \\
\hline \multicolumn{6}{|l|}{ Red-Slipped } \\
\hline ext. red-slipped & - & $7+$ & - & - & 7 \\
\hline int./ext red-slipped & $2 * *$ & 8 & - & 1 & 11 \\
\hline Totals & 5 & 25 & 1 & 2 & 33 \\
\hline
\end{tabular}

*includes one body sherd with interior/exterior red-slipped surfaces

**includes one rim with ext. thickened lip/rim node +includes a base sherd with an exterior red-slipped surface

$\mathrm{L}-\mathrm{R}$, left (engraved line begins at top of rim) to right (engraved line ends to the right at bottom of rim); R-L, right (engraved line begins at the top of rim) to left (engraved line ends to the left at bottom of rim)

One engraved rim sherd has at least two sets of closely-spaced horizontal engraved lines (Figure 4b), and another has several equally spaced horizontal engraved lines (see Table 3), but the remainder of the A. C. Gibson fine ware sherds are from Sanders Engraved carinated bowls (see Suhm and Jelks 1962:137 and Plate 69). These engraved sherds have cross-hatched (Figure 4e), diagonal, horizontal and diagonal opposed lines (Figure 4g), and diagonal opposed (Figure 4a, f) engraved lines.

One of the more distinctive Sanders Engraved sherds from the A. C. Gibson fine ware assemblage is a body sherd from a carinated bowl with interior and exterior red-slipped surfaces. The sherd has parallel engraved lines - likely oriented horizontally on the vessel as border lines - with large excised pendant triangles from one of the lines (see Figure 4c). These large excised pendant triangles are likely part of a continuous series of triangles around the vessel rim. 


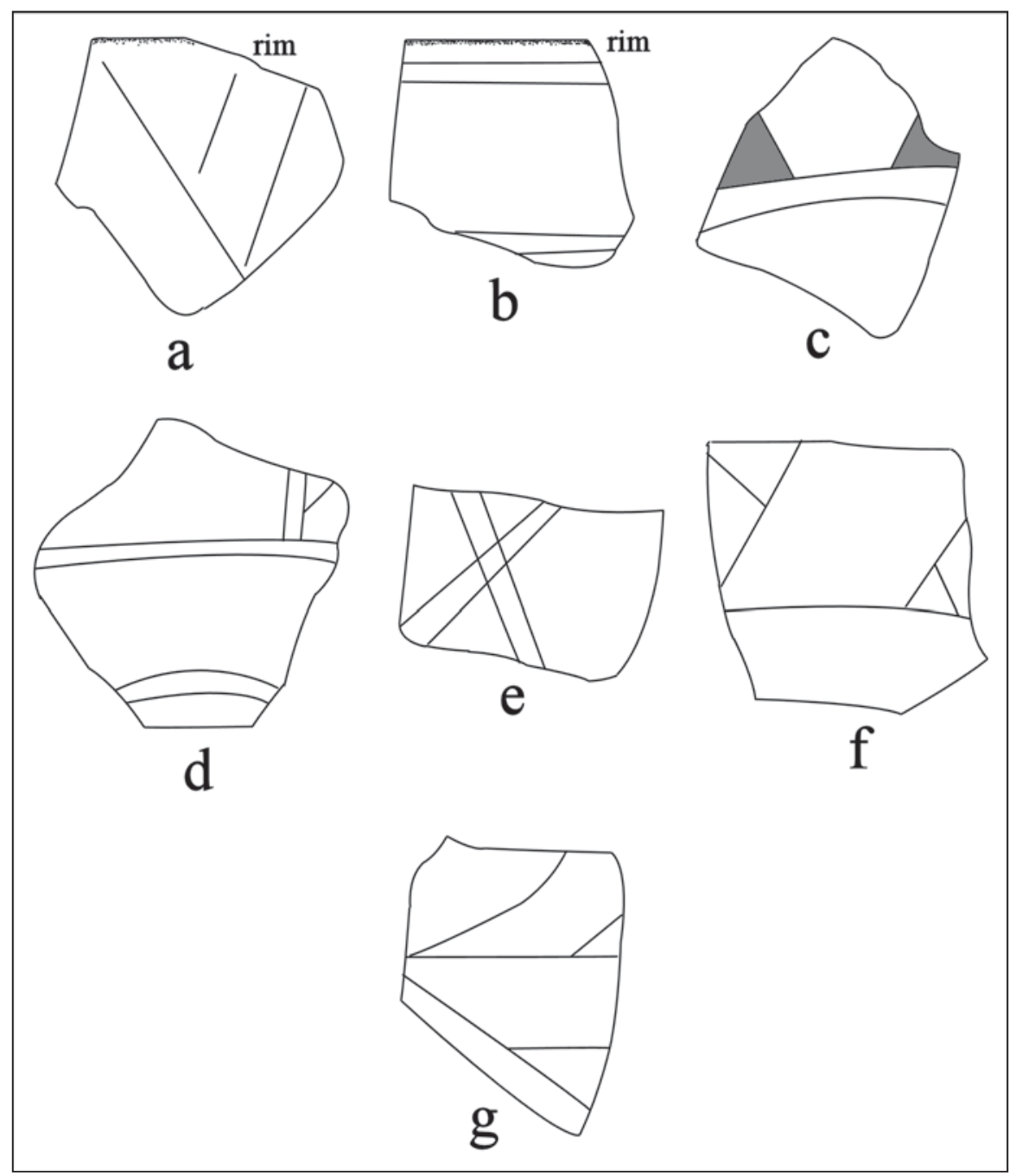

Figure 4. Decorative elements on fine ware rim and body sherds from the A. C. Gibson site: a-b, engraved rim sherds; c-g, engraved body sherds.

Three of the engraved sherds are from bottles. Two sherds have either curvilinear or straight lines, while the third bottle sherd has sets of curvilinear lines as well as vertical and diagonal lines (see Figure 4d).

The red-slipped sherds are from Sanders Plain vessels, including carinated bowls, bowls, and bottles. As redefined by Brown (1996:401-403 and Figures 2-191, 2-34g, 2-37a-1, 2-38d, 2-39d, k, n-q, and 2-42b), Sanders Plain is a grog-tempered, slipped, and undecorated type found widely across the Caddo area. Vessel forms include bowls, carinated bowls, and narrow and wide-mouthed bottles. One slipped rim sherd from a carinated bowl has an exterior-thickened node at the exterior edge of the flat lip, and the other is from a bowl with a short everted rim and a flat lip.

The very high proportions of red-slipped vessels in the ceramic sherd assemblage at the A. C. Gibson site is notable. Where attribute-level information is available on decorative elements in sherd assemblages, assemblages with considerable amounts of red-slipped sheds are found in the upper Sabine River basin in sites occupied in the Middle Caddo period, along with contemporaneous sites in the middle Red River and the upper Sulphur River basin (Perttula 2015:Figure 3 and Table 1). 


\section{Ceramic Pipes}

Two sherds from two different pipes and a whole pipe have been found at the A. C. Gibson site. The first of the sherds is the flat butt or distal end of a Red River long-stemmed pipe, tempered with burned bone. The stem itself is $8.9 \mathrm{~mm}$ in diameter, and the stem hole diameter is $3.7 \mathrm{~mm}$; this sherd appears to be from a Graves Chapel variety of long-stemmed pipe (Hoffman 1967:9 and Figure 4b).

The second pipe sherd is a flat lipped rim sherd from a grog-tempered elbow pipe, probably similar to a variety of elbow pipes from the Early Caddo Taddlock site (41WD482) at Lake Fork Reservoir (Bruseth and Perttula 1981:91 and Figure 5-11a-b) and Middle Caddo sites elsewhere in East Texas (Rogers and Perttula $2004: 289,291)$ that have rounded heels, large bowls (26-45 $\mathrm{mm}$ in diameter) and large stem diameters (26$35 \mathrm{~mm}$ ). The A. C. Gibson elbow pipe rim sherd has a $30.2 \mathrm{~mm}$ bowl height, $5.2 \mathrm{~mm}$ thick walls, and an orifice diameter of at least $19.2 \mathrm{~mm}$. These elbow pipes are stylistically and morphologically distinct from smaller post-A.D. 1400/1450 elbow pipes in East Texas in that the latter have "short thick stems and large conical stem holes" (Hoffman 1967:10), as well as large diameter bowls. The whole pipe from Burial S-2 at the A. C. Gibson site (Figure 5) is an example of this earlier form of elbow pipe in that it has a rounded heel, with little difference in size or diameter between the pipe bowl or the stem hole.

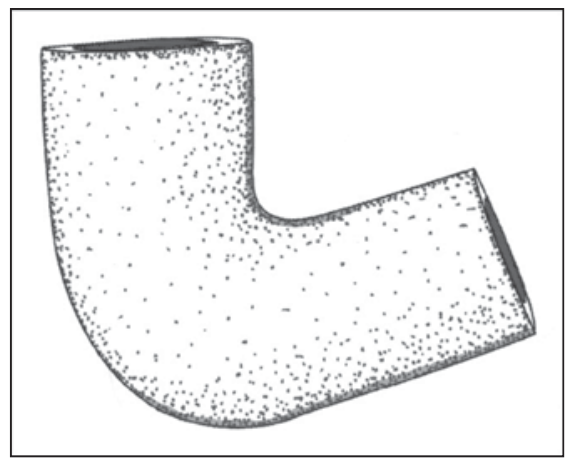

Figure 5. Elbow pipe from Burial S-2 at the A. C. Gibson site.

\section{SUMMARY AND CONCLUSIONS}

The A. C. Gibson site (41WD1) is on an alluvial knoll in the Sabine River floodplain, in the upper Sabine River basin in the Post Oak Savannah of East Texas. Midden deposits accumulated from the prehistoric occupation of the knoll, and these occupations occurred during the Late Archaic, Woodland, and Middle Caddo periods. The latter occupation by ancestral Caddo peoples was the principal occupation at the site, and likely the occupation that mainly contributed to the accumulation of midden deposits at the site.

The Middle Caddo period component at the A. C. Gibson site is defined based on the presence of an early stylistic form of East Texas elbow pipe and the character of the grog-tempered utility ware and fine ware sherds and vessels found in the midden during excavations by University of Texas archaeologists in 1934. During the 1934 investigations of the midden deposits at the site, two burial features (Burial S-1 and S-2) were excavated, the first a flexed child (Burial S-1) and the second a burial with two individuals placed in an extended supine position (Burial S-2), but with their heads at opposite ends of the grave, one facing east and the other individual facing west. No clear funerary offerings were identified in Burial S-1, and because it is a flexed burial, it is possible that it is a Woodland period interment. Burial S-2, on the other hand, is clearly a Middle Caddo burial feature with several funerary offerings, including the aforementioned elbow pipe, a Sanders Plain jar, and a bowl with appliqued lip nodes. 
The assemblage of sherds from ceramic vessels in the midden deposits at the A. C. Gibson site indicate that utility wares, plain wares, and fine wares were in common use by the ancestral Caddo peoples that lived there. Utility ware types in the sherds principally include Canton Incised jars with several distinctive decorative elements, as well as Monkstown Fingernail Impressed vessels with punctated, pinched, appliqued, and appliqued-punctated decorative elements. The fine ware sherds in the assemblage are dominated by red-slipped Sanders Plain carinated bowls and bottles and Sanders Engraved carinated bowls. Although not identified to type, there are also several engraved bottle sherds in the assemblage.

\section{ACKNOWLEDGMENTS}

Lance Trask prepared the figures for this article, and Jonathan Jarvis facilitated my access to the records

and collections from the A. C. Gibson site at the Texas Archeological Research Laboratory at The University of Texas at Austin.

\section{References Cited}

Brown, J. A.

1996 The Spiro Ceremonial Center. The Archaeology of Arkansas Valley Caddoan Culture in Eastern Oklahoma. 2 Vols. Memoir No. 29. Museum of Anthropology, University of Michigan, Ann Arbor.

Bruseth, J. E. and T. K. Perttula

1981 Prehistoric Settlement Patterns at Lake Fork Reservoir. Texas Antiquities Permit Series, Report No. 2. Texas Antiquities Committee and Southern Methodist University, Austin and Dallas.

Hoffman, M. P.

1967 Ceramic Pipe Style Chronology Along the Red River Drainage in Southwestern Arkansas. The Arkansas Archeologist 8(1):4-14.

Malone, J. M.

1972 Archaeological Reconnaissance at Proposed Mineola Reservoir. Archeological Survey Report No. 10. Texas Historical Survey Committee, Austin.

Perttula, T. K.

2015 East Texas Caddo Ceramic Sherd Database. Journal of Northeast Texas Archaeology 51:1-46.

Rogers, R. and T. K. Perttula

2004 The Oak Hill Village (41RK214), Rusk County, Texas. Document No. 030083. PBS\&J, Austin.

Schambach, F. F.

1982 An Outline of Fourche Maline Culture in Southwest Arkansas. In Arkansas Archeology in Review, edited by N. L. Trubowitz and M. D. Jeter, pp. 132-197. Research Series No. 15. Arkansas Archeological Survey, Fayetteville.

Suhm, D. A. and E. B. Jelks (editors)

1962 Handbook of Texas Archeology: Type Descriptions. Special Publication No. 1, Texas Archeological Society, and Bulletin No. 4, Texas Memorial Museum, Austin. Reprinted in 2009, Gustav's Library, Davenport, Iowa.

Turner, E. S., T. R. Hester, and R. L. McReynolds

2011 Stone Artifacts of Texas Indians. Third Edition. Taylor Trade Publishing, Lanham, Maryland. 